\title{
Employment of the 18s rRNA screening PCR technique in the detection of Equine Piroplasmosis, in horses of sports and military operations, of the Brazilian Army
}

\author{
[Emprego da técnica de PCR para triagem da região do genoma 18s rRNA, detecção de Piroplasmose \\ em equinos de desporto e operações militares do Exército Brasileiro] \\ C.P. Sousa ${ }^{1}$, J.G.B. Soares ${ }^{2 *}$ \\ ${ }^{1}$ Universidade Federal de São Carlos - São Carlos, SP \\ ${ }^{2}$ Aluno de pós-graduação - Universidade Federal de São Carlos - São Carlos, SP
}

\begin{abstract}
The present work had the objective of detecting the occurrence of Equine Piroplasmosis in horses housed in the 3rd Guards Cavalry Regiment (GCR) - Brazilian Army (BA) - Porto Alegre, RS-Brazil, as well as to demonstrate the proactivity of PCR (Polymerase Chain Reaction) technique, aiming at the judicious use of the resources involved in the training and employment of Equines in the Brazilian Army. Fifty horses of the 3rd GCR - Porto Alegre - RS, which are employed for Sport, Military Ceremonial, Law and Order Guarantee Operations (LOGO), were evaluated by means of the 18s r RNA screening with PCR technique, thirty eight horses with Babesia Caballi and Theileria Equi were detected, which corresponds to an incidence of $76 \%$ of the horses effective analyzed at the time. In this way, it can be verified that the Military activity have its "performance and effectiveness" factors threatened in case the health of the principal of his means employed, that is the horse, is compromised. The PCR technique then offers a reliable and feasible tool for the detection of Equine Piroplasmosis in BA horses.
\end{abstract}

Keywords: Horses, Babesia Caballi, Detection, PCR, LOGO, GCR, BA

\section{RESUMO}

O presente trabalho teve como objetivo detectar a ocorrência de Piroplasmose equina em cavalos alojados no $3^{\circ}$ Regimento de Cavalaria de Guarda (RCG) - Exército Brasileiro (EB) - Porto Alegre, RS, Brasil, bem como demonstrar a forma proativa do método da PCR (reação em cadeia de polimerase), objetivando o uso criterioso dos recursos envolvidos no treinamento e emprego de equinos no Exército Brasileiro. Foram avaliados 50 cavalos da $3^{a}$ GCR-Porto Alegre, RS, empregados nas modalidades de: esporte, cerimonial militar e operações de garantia da lei e da ordem (GLO), por meio da triagem da região do genoma $18 S$ rRNA mediante a aplicação do método da PCR. Foram positivas as amostras de 38 equinos para Babesia caballi e Theileria Equi, o que corresponde a uma incidência de $76 \%$ dos cavalos efetivos analisados na época. Dessa forma, verifica-se que as atividades militares tem seus fatores de "desempenho e efetividade" ameaçados no caso da saúde do principal de seus meios empregados, o Cavalo, estar comprometida. A técnica de PCR, então, oferece uma ferramenta confiável e viável para a deteç̧ão de Piroplasmose em equinos do EB.

Palavras-chave: Cavalos, Babesia Caballi, Detecção, EB.

\section{INTRODUCTION}

Equine Piroplasmosis is a tick-transmitted intra erythrocytic parasitic disease of horses, the small piroplasm of horses (Bruning, 1996), long known as Babesia Equi, is already commonly designated associated with fever, hemolytic

Recebido em 17 de julho de 2017

Aceito em 14 de novembro de 2017

*Autor para correspondência ( corresponding author)

E-mail: jgbernardi@hotmail.com anemia, and haemoglobinuria (De Tarso; Botteon, 2005), loss of athletic performance and can lead to death, caused by either Babesia Caballi or Theileria Equi (Fonseca, 2012).

B. Caballi and T. Equi, are presented in temperate as well as in tropical regions. Fourteen species of ixodid ticks of the genera 
Dermacentor, Hyalomma, and Rhipicephalus have been identified worldwide as vectors of either T. Equi or B. Caballi. (Garci et al., 2004).

Equine piroplasmosis diagnostics can be serological tests such as: an enzyme-linked immunosorbent assay (Santos et al., 2009), an indirect fluorescent antibody test (Mullan, 2016) immune chromatographic tests, or alternatively on identification of the agent by microscopic examination or molecular tools (Nagore et al., 2004). Many PCR methods have been described recently (Weiland et al., 1986), including single round and multiplex PCR, to allow simultaneous identification of both B. Caballi and T.equi (Alhassan et al., 2005), PCR - reverse line blot hybridization ( Butler et al, 2008), and real-time PCR(Bhoora, 2010).

The Brazilian Army has about 1,876 horses distributed in almost all Brazilian territory (Brazil, 2017), in several military several Cavalry Regiment Units $\left(1^{\circ}, 2^{\circ}, 3^{\circ}\right)$; employees in LOGO, participation in Military Ceremonial such as Parades, Guard and Escorts; Patrolling in Military Organizations and in the Fields of Instruction; Military Training in official and squad Training Schools, Military Academy of Agulhas Negras (AMAN), Army Sergeants School (EsSA), Army Riding School (EsEQEx), and the Rincão- São Borja Stud - RS (Campos, 2015).

Piroplasmosis causes numerous economic losses (Ferreira et al., 2016) with the loss of performance of horses (Oliveira, 1918), being a variable of failure, with a zoonosis which is a threat to the health of the human component used in military activities indeed may be transmitted to another animals (Fritz, 2010).

The sensitivity of the PCR assay is higher than that of a classical microscopic examination (Jaffer et al, 2010).

The aim of this study was the application of the18s r RNA screening with PCR method, in addition to its economic viability, sensitivity and selectivity, and in the future can be

recommended for use in the Military Units of the $\mathrm{BA}$, for the diagnosis of Equine Piroplasmosis.

\section{MATERIALS AND METHODS}

This study has been approved by the Ethics Committee in Animal Experimentation and Animal Welfare at the Universidade Federal de São Carlos, (protocol number CEUA 8586190816/16), S ão Paulo State, Brazil.

Blood samples of 50 horses housed in the 3rd. GCR located in the city of Porto Alegre, RS, were evaluated among these equine sports, ceremonial, and employees in the LOGO operations, collected by veterinarians from the veterinary section of the regiment in the month of December 2016.

Blood samples were submitted to the extraction protocol from blood, using Brazol®-LGC protocol of extraction of genomic DNA.

The $100 \mu \mathrm{L}$ of blood was added to a $1.5 \mathrm{ml}$ tube already containing $200 \mu \mathrm{L}$ of Brazol (LCG Biotechnology, São Paulo, Brazil).

After the solution was homogenized for 2 minutes, $50 \mu \mathrm{L}$ of chloroform and the homogenized solution were added. The sample was then centrifuged at $13,000 \mathrm{~g}$ for 15 minutes. After this step, the supernatant (aqueous phase) was transferred to a new labeled tube and $200 \mu \mathrm{L}$ of Isopropanol cooled at $4^{\circ} \mathrm{C}$ was added thereto. The solution was centrifuged at $13,000 \mathrm{~g}$ for 20 minutes. The supernatant was then discarded and $800 \mu \mathrm{L}$ of absolute ethanol PA was added. The material was centrifuged at $13,000 \mathrm{~g}$ for 10 minutes and the supernatant discarded. The precipitate was washed with $500 \mu \mathrm{L}$ of $70 \%$ ethanol and centrifuged at $13,000 \mathrm{~g}$ for 10 minutes. The supernatant was discarded and after drying the precipitate was suspended in $30 \mu \mathrm{L}$ of ultra-pure autoclaved water or T.E. (10mM Tris $\mathrm{pH}$ 8.0, 1mM EDTA $\mathrm{pH} 8.0$ ) and stored in a freezer at $-20^{\circ} \mathrm{C}$.

The nucleotide sequences of the primers used in this study to the PCR amplifications of $18 \mathrm{~s} \mathrm{r}$ RNA gen, (Table 1) were performed according to previously published procedures (Spolidorio et al., 2011). 
Table 1. Primers table used to detect Babesia Caballi and Theileria Equi in Horses of Brazilian Army

\begin{tabular}{|c|c|c|c|c|}
\hline $\begin{array}{l}\text { Babesia } \\
\text { spp. } \\
\text { Theileria } \\
\text { spp. }\end{array}$ & $\begin{array}{c}\text { BAB } \\
143-167 \\
\text { BAB } \\
694-667\end{array}$ & $\begin{array}{l}\text { CCGTGCTAATTGTAGGGCTAATACA } \\
\text { GCTTGAAACACTCTARTTTTCTCAAAG }\end{array}$ & $\begin{array}{l}\text { Size } \\
551 \mathrm{bp}\end{array}$ & $\begin{array}{l}\text { Spolidorio et } \\
\text { al., } 2011\end{array}$ \\
\hline
\end{tabular}

For the PCR amplification reactions, a Taq DNA Polymerase enzyme was used in reactions with a final volume of $15 \mu \mathrm{L}$. For this volume, the reaction was prepared with $1 \mathrm{U}$ of enzyme; $1 \mathrm{X}$ buffer solution; $0.2 \mathrm{mM}$ of the phosphate deoxy ribonucleotide solution (dNTPs) and $10 \mathrm{pmol}$ of each primer. $1 \mu \mathrm{L}$ of the DNA extracted from each sample was used as template DNA; Reagents and their respective volumes used for each amplification reaction (Table 2), were performed according to previously published procedures (Spolidorio et al., 2011) and the thermal cycle ( Table 3). An additional reaction was performed as a negative control in which the volume relative to the template DNA was replaced by $1 \mu \mathrm{L}$ of sterile water.

The amplification products (Figure 1.) were then subjected to electrophoresis in agarose gel 2\% buffered solution containing $40 \mathrm{mM}$ Tris-acetate $\mathrm{pH} 8.0 ; 1 \mathrm{~mm}$ EDTA (TAE buffer solution) for $30 \mathrm{~min}$ at $110 \mathrm{~V}$. For viewing through the traviolet (UV) region, was used the DNA intercalating etílio bromide.
Table 2. Reagents and their respective volumes used for each amplification reaction of Babesia Caballi and Theileria Equi

\begin{tabular}{lc}
\hline \multicolumn{1}{c}{ Reagents } & 1 Reaction $(\mu \mathrm{l})$ \\
\hline Buffered (10X) & 1.5 \\
Mg Cl (50 mM) & 0.45 \\
DNTPs (1,25mM) & 2.4 \\
Primer F (10 p Mol) & 1.0 \\
Primer R (10 p Mol) & 1.0 \\
Enzyme Taq Polymerase & 0.2 \\
DNA Template & 1.0 \\
$\mathrm{H}_{2} \mathrm{O}$ & 7.45 \\
\hline
\end{tabular}

Table 3. Thermal cycle

\begin{tabular}{cc}
\hline Temperatures $\left({ }^{\circ} \mathrm{C}\right)$ & Time $(\mathrm{min})$ \\
\hline 94 & 5 \\
94 & $30 \mathrm{seg} .-40 \mathrm{x}$ \\
56 & $30 \mathrm{seg} .-40 \mathrm{x}$ \\
72 & $30 \mathrm{seg} .-40 \mathrm{x}$ \\
72 & 10 \\
4 & Hold \\
\hline
\end{tabular}

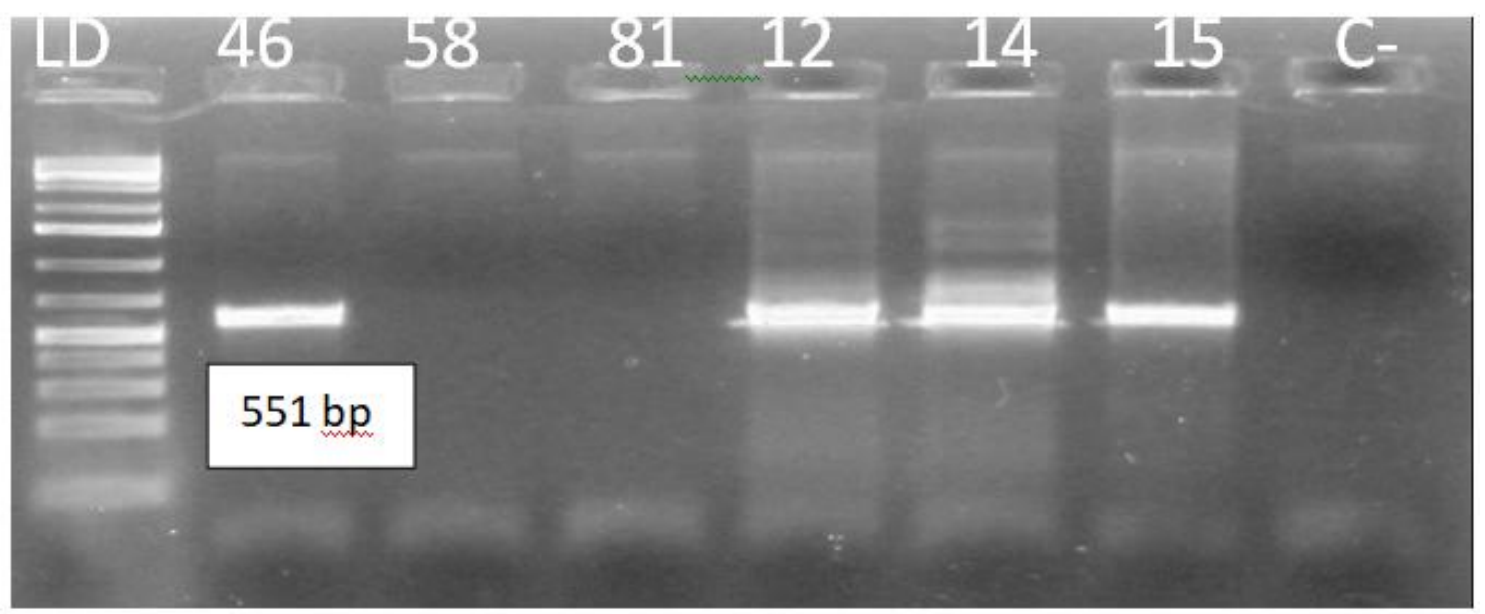

Figure 1. PCR products: LD - Ladder-; Positive probes: 46, 12, 14, 15; Negative Probes; 58, 81; C- Negative control, characterizing the reaction for the specific band of 551 base pairs, expected amplification for positives of Babesia Caballi and Theileria Equi. 


\section{RESULTS AND DISCUSSION}

The PCR products were submitted to genetic sequencing (GENOTYPING - LABORATORIO DE BIOTECNOLOGIA LTDA-Botucatu-SPBrazil) using Big Dye terminator v3.1 Cycle Sequencing kit (thermofisher), ethanol / EDTA / sodium acetate precipitation, according to the manufacturer's instructions in automatic sequencer (ABI PRISM-3500 Genetic Analyzer). The sequences obtained were edited in the CHROMA software (http://technelysium.com.au/ wp/Chromas/), and similarity levels were analyzed through the Basic Local Alignment Search Tool (BLAST) program in order to verify the identity with other corresponding sequences available in Gen Bank.

The 38 positive samples showed $100 \%$ similarity to the samples with the Babesia Caballi sequence (Gen Bank AB734392), and with Theileria Equi sequence available on Gen Bank (JX049129).

To our knowledge, this paper is the first to report on the identification of both $T$. Equi and $B$. Caballi, with the aim to perform the employment of the horse sources, inside an Operational headquarter, through the PCR techniques application to this goal.

\section{CONCLUSION}

The PCR technique was shown to be an effective tool for the detection and prevention of Babesia Equi and Theileria Equi. The economic feasibility of applying animal health screening in BA is favorable, since the costs are low, also the time of the results and their effectiveness were proven in this study. Based on the results of the present study, it is economically feasible to apply animal health, the application of the PCR method for the detection of equine piroplasmosis, in addition to its economic viability, sensitivity and selectivity, could in the future be recommended for Prevention and improvement of Equine Health in the Brazilian Army. None of the authors of this paper have a financial or personal relationship, with other people or organization that could inappropriately influence or bias the content of the paper.

\section{ACKNOWLEDGMENTS}

The authors want to thanks to Dr. Rafael Rodrigues, Dr. Renata de Lima Antunes, Dr Juliana Azevedo Gonçalves, Veterinary Doctors of Brazilian Army, Dr Bruno Garcia RochaDNA Consult, as well as Colonel Fernando Cunha De Almeida Commander of the 3rd Guards Cavalry Regiment (GCR) - Brazilian Army (BA) - Porto Alegre, RS-Brazil, for their kind collaboration.

\section{REFERENCES}

ALHASSAN A.; PUMIDONMING W.; OKAMURA M. et al. Development of a single round and multiplex PCR method for the simultaneous detection of Babesia caballi and Babesia equi in horse blood. Vet. Parasitol., v.129, p.43-49, 2005.

BHOORA, R.; QUAN, M.; FRANSSEN, L. et al. Development and evaluation of real-time PCR assay for the quantitative detection of Babesia caballi and Theileria equi infections in horses from South Africa. Vet. Parasitol., v.168, p.201-211, 2010.

BRASIL, Boletim do Exército, nº6/2017.

BRUNING, A. Equine piroplasmosis an update on diagnosis, treatment and prevention. Br. Vet. J., v.152, p.139-151, 1996.

BUTLER, C.M.; NIJHOF, A.M.; KOLK, J.H. et al. Repeated high dose imidocarb dipropionate treatment did not eliminate Babesia caballi from naturally infected horses as determined by PCRreverse line blot hybridization. Vet. Parasitol. v.151, p.320-322, 2008.

CAMPOS - $2015 \quad$ C.H.C. Aspectos epidemiológicos de Theileria equi, Babesia caballi e Borrelia spp em equinos de uso militar das regiões Sudeste e Sul do Brasil Carlos. 2015.

DE TARSO, P.; BOTTEON, L. Babesiose em cavalos atletas portadores. Cienc. Rural, v.35, 8p., 2005

FERREIRA, E.P. et al. Serological and molecular detection of Theileria equi in sport horses of northeastern Brazil. Comp. Immunol. Microbiol. Infect. Dis, v.47, p.72-76, 2016. 
FONSECA, L.A. Reação em cadeia da polimerase (PCR) de sangue periférico $e$ esplênico para diagnóstico de babesiose equina. 41f. 2012. Dissertação (Mestrado em Saúde Animal) - Universidade de Brasília, Brasília, DF.

FRITZ, D.A. PCR study of piroplasms in 166 dogs and 111 horses in France (March 2006 to March 2008). Parasitol. Res., v.106, p.13391342, 2010.

GARCI, A.L.; NAGORE, D., GARCÍASANMARTÍN, J. et al. Identification, genetic diversity and prevalence of Theileria and Babesia species in a sheep population from Northern Spain. Int. J. Parasitol., v.34, p.1059-1067, 2004.

JAFFER, O.; ABDISHAKUR, F.; HAKIMUDDIN, F. et al. Comparative study of serological tests and PCR for the diagnosis of equine piroplasmosis. Parasitol. Res., v.106, p.709-713, 2010.

MULLAN-2016, S. Polymerase chain reaction: an important tool for early diagnosis of leptospirosis cases. J. Clin. Diag. Res., v.10, 2016.
NAGORE D.; GARCIA-SANMARTIN, J.; GARCIA-PEREZ, A.L. et al. Detection and identification of equine Theileria and Babesia species by reverse line blotting: epidemiological survey and phylogenetic analysis. Vet. Parasit. v.123, p.41-54, 2004.

OLIVEIRA, L.C. Tributário A atividade equestre no Brasil: movimentação econômica e tributação incidente. 1918. http://ambito-juridico.com.brDez17.

SANTOS, T.M. et al. Comparative studies of three methods for detection Theileria equi antibody in endemic areas horses from Rio de Janeiro state. Braz. J. Vet. Res. Anim. Sci. v.46, p.484-490, 2009.

SPOLIDORIO, M.G. et al. Molecular detection of Hepatozoon canis and Babesia canis vogeli in domestic dogs from Cuiabá, Brazil. Rev. Bras. Parasitol. Vet., v.20, p.253-255, 2011.

WEILAND, G. Species-specific serodiagnosis of equine piroplasma infections by means of complement fixation test (CFT), immunofluorescence (IIF), and enzyme linked immunosorbent assay (ELISA). Vet. Parasitol., v.20, p.43-48, 1986. 